\title{
KEPATUHAN BEROBAT PENDERITA HIPERTENSI DI WILAYAH KERJA PUSKESMAS PAYANGAN KABUPATEN GIANYAR
}

\author{
I Nyoman Purnawan \\ Program Studi Kesehatan Masyarakat, Universitas Dhyana Pura \\ Email: purnawankomink@undhirabali.ac.id
}

\begin{abstract}
ABSTRAK
Kepatuhan terhadap pengobatan merupakan salah satu faktor yang menentukan keberhasilan terapi penderita hipertensi. Penelitian ini bertujuan untuk mengidentifikasi tingkat kepatuhan dan menganalisis faktor yang berhubungan. Penelitian ini merupakan penelitian kuantitatif dengan rancangan cross-sectional yang dilaksanakan di wilayah kerja Puskesmas Payangan, Gianyar-Bali pada bulan Mei-Juni 2015. Populasi adalah seluruh penderita hipertensi yang tercatat dalam data rekam medis di Puskesmas Payangan. Prosedur pemilihan sampel menggunakan teknik simple random sampling. Data dikumpulkan dengan melakukan wawancara menggunakan kuesioner di rumah penderita hipertensi. Pengukuran kepatuhan dilakukan dengan menggunakan kuesioner MMAS-8 (Morisky Medication Adherence Scale-8). Faktor predisposisi, faktor pemungkin dan faktor penguat dianalisis sebagai faktor yang berhubungan dengan kepatuhan menggunakan uji Chi-square dan regresi logistik. Hasil penelitian menunjukkan dari total 242 responden yang dilibatkan dalam penelitian diketahui bahwa $41,32 \%$ patuh dan $58,68 \%$ tidak patuh melakukan pengobatan. Terdapat hubungan bermakna antara komorbiditas $(\mathrm{p}=0,007)$ dan ketersediaan obat $(\mathrm{p}=0,045)$ dengan kepatuhan berobat. Berdasarkan analisis regresi logistik diketahui bahwa komorbiditas merupakan variabel yang paling dominan berhubungan dengan kepatuhan berobat $(\mathrm{p}=0,006, \mathrm{OR}=3,943, \mathrm{CI}$ 95\%=1,470-10,575). Kesimpulan dari penelitian ini adalah kepatuhan berobat pasien hipertensi masih rendah. Untuk memaksimalkan kepatuhan, perlu meningkatkan interaksi profesional kesehatan diantara pasien tanpa komorbiditas.
\end{abstract}

Kata Kunci: kepatuhan berobat, hipertensi, MMAS-8, Puskesmas, Payangan, Bali

\begin{abstract}
For patients with hypertension, adherence to treatment is one of the factors that determines the success of therapy. A survey was conducted to identify adherence patterns and explore predisposing, enabling and amplifying factors that associated with adherence to treatment among hypertensive patients. A crosssectional study was conducted among hypertensive patients registered in Payangan village health center medical records. Respondents were selected using simple random sampling from the register. Data were collected in May-June 2015 through interviews at patient homes. Adherence to treatment was measured using MMAS-8 (Morisky Medication Adherence Scale) containing 8 questions. Sociodemographic factors, knowledge, comorbidities, family history of hypertension and attitude to treatment were predisposing factors explored. Availability of drugs, accessibility of drug, perception of distance, availability of transportation, ease of drug consumption were enabling factors explored. Family support, health worker support, health insurance, exposure to health information were reinforcing factors explored. We constructed a Chi-square test and logistic regression model to explore as factors associated with adherence. Results of 242 respondents, $41.32 \%$ were adherent and $58.68 \%$ were non-adherent to treatment. Factors included having comorbidities ( $p$ value $=0.007$ ) and availability of drugs ( $p$ value $=0.045$ ) have a associate with adherence. Using a logistic regression model, comorbidities have most dominant to associated with adherence to treatment ( $p$ value $=0.006, O R=3.943, C I 95 \%=1.470-10.575$ ). Adherence to treatment is low among hypertensive patients. The existence of comorbidities associated with adherence to treatment. To maximize likelihood of adherence, need to improve the health professional interaction among non-comorbidities patients.
\end{abstract}

Keywords: adherence to treatment, hypertension, MMAS-8, healthcare center, Payangan, Bali

\section{PENDAHULUAN}

Di berbagai belahan dunia, trend kasus hipertensi diperkirakan akan meningkat tajam sampai tahun 2025 yaitu terdapat sekitar 29\% penderita hipertensi. Dimana sekitar $80 \%$ kenaikan kasus hipertensi terjadi terutama di negara-negara berkembang (WHO, 2013). Di Indonesia, hipertensi masih menjadi masalah kesehatan masyarakat walaupun sudah ada pedoman penanganan maupun hasil penelitian 
yang bersakala nasional (Kemenkes RI, 2007). Angka prevalensi hipertensi rata-rata meliputi $17 \%$ - $21 \%$ dari keseluruhan populasi orang dewasa, artinya 1 diantara 5 orang dewasa telah menderita hipertensi. Provinsi Bali yang pada tahun 2012 mempunyai angka prevalensi lebih rendah (7\%) dari keseluruhan populasi, telah mengalami peningkatan kasus pada tahun-tahun berikutnya, seperti yang terjadi pada tahun 2013 (Kemenkes RI, 2007). Di Provinsi Bali, prevalensi hipertensi tahun 2013 tertinggi terjadi di Kabupaten Gianyar (Dinas Kesehatan Provinsi Bali, 2013). Dinas Kesehatan Kabupaten Gianyar mencatat bahwa selama tahun 2013 prevalensi penyakit hipertensi mencapai angka 19\%. Dari data sekunder penyakit tidak menular di Dinas kesehatan Kabupaten Gianyar dilaporkan bahwa penderita hipertensi dengan prevalensi tertinggi terdapat di wilayah kerja Puskesmas Payangan yaitu sekitar 13\% (Dinas Kesehatan Kabupaten Gianyar, 2013). Saat ini data tersebut dijadikan patokan dalam menganalisis tindakan pengendalian penyakit hipertensi.

Bagi penderita hipertensi, kepatuhan terhadap pengobatan merupakan salah satu faktor yang menentukan keberhasilan terapi (WHO, 2012). Namun, kepatuhan terhadap pengobatan seringkali rendah. Survei sebelumnya di Bangladesh, menunjukkan 26\% ketidakpatuhan terhadap pengobatan dari jumlah sampel 29.960 pria dan wanita yang berusia 25 tahun ke atas (Khanam, et al., 2014). Sebelumnya, studi pendahuluan telah dilakukan di wilayah kerja Puskesmas Payangan pada tahun 2014 menunjukkan bahwa motivasi dan kepatuhan penderita terhadap pengobatan penyakit hipertensi masih rendah. Dalam pengobatan hipertensi, sangat penting untuk memastikan diagnosis yang tepat, pemilihan obat dan administrasi yang tepat oleh tenaga kesehatan. Namun, ini tidak menjamin keberhasilan pengobatan jika pasien tidak mematuhi prosedur pengobatan (Dusing, et al., 2001). Ketidakpatuhan pasien terhadap pengobatan merupakan masalah serius dan sering terjadi pada pasien dengan penyakit kronis. Untuk mencapai keberhasilan dalam pengobatan, sejumlah faktor dapat dihubungkan, seperti karakteristik pasien, hubungan antara petugas kesehatan dengan pasien, dan sistem penyelenggaraan pelayanan kesehatan (Amelia. $\mathrm{H}$, 2011). Faktor-faktor ini belum pernah diteliti pada pasien hipertensi di wilayah kerja Puskesmas Payangan. Penelitian ini dilakukan dengan tujuan untuk mengetahui tingkat kepatuhan berobat dan menganalisis faktor-faktor yang berhubungan dengan kepatuhan berobat pasien hipertensi.
Faktor-faktor tersebut akan mencakup faktor predisposisi, faktor pemungkin dan faktor penguat (Saeed, 2012).

\section{METODE PENELITIAN}

Penelitian ini merupakan penelitian kuantitatif dengan rancangan cross- sectional dengan melibatkan pasien hipertensi yang tercatat dalam data rekam medis di Puskesmas Payangan Kabupaten Gianyar Provinsi Bali mulai bulan Mei- Juni 2015. Pasien yang dilibatkan sebagai responden adalah pasien yang saat penelitian telah melakukan pengobatan minimal 2 bulan sebelumnya, tercatat dalam data rekam medis untuk pengobatan dan berdomisili di wilayah kerja Puskesmas Payangan melalui tehnik simple random sampling. Pengukuran tingkat kepatuhan dilakukan dengan menggunakan kuesioner MMAS-8 (Morisky Medication Adherence Scale) dengan 8 pertanyaan yang telah diterjemahkan ke dalam Bahasa Indonesia, dimana pasien dikategorikan patuh apabila skor MMAS-8 diperoleh $\geq 6$ dan sebaliknya Morisky, 2008). Kuesioner MMAS-8 telah terbukti cukup valid dan reliable untuk digunakan sebagai alat ukur kepatuhan berobat pasien hipertensi (Yashar. M, dkk., 2014). Pada penelitian ini, kuesioner diisi oleh pengumpul data melalui proses wawancara di rumah pasien hipertensi. Pasien yang memenuhi kriteria dan bersedia menjadi responden penelitian, kemudian diminta untuk mengisi formulir persetujuan tertulis (informed consent). Beberapa informasi terkait faktor predisposisi (jenis kelamin, usia, pendidikan, pekerjaan, pendapatan keluarga per- bulan, lama terdiagnosa hipertensi, pengetahuan, komorbiditas, riwayat keluarga hipertensi, sikap untuk pengobatan), faktor pemungkin (ketersediaan obat, aksesibilitas obat, persepsi jarak, ketersediaan transportasi, kemudahan konsumsi obat), dan faktor penguat (dukungan keluarga, dukungan petugas kesehatan, asuransi kesehatan, keterpaparan informasi) juga diperoleh melalui wawancara. Data yang sudah terkumpul akan dilakukan pengolahan yang kemudian dianalisa menggunakan program Stata versi 12 dengan analisis univariat, bivariat (Chi-square), dan multivariat (regresi logistik model) (Riyanto.A, 2010).

\section{HASIL}

Gambaran karakteristik responden tersaji pada Tabel 1 di bawah ini. Hasil analisis univariat menunjukan bahwa dari total 242 responden, sebanyak $100(41,32 \%)$ pasien patuh untuk berobat sedangkan sebanyak $142(58,68 \%)$ pasien tidak patuh untuk berobat. 
Tabel 1. Karakteristik responden penelitian

\begin{tabular}{|c|c|c|c|c|c|c|}
\hline Variabel & $\begin{array}{l}\text { Patuh } \\
\text { (orang) }\end{array}$ & $\%$ & $\begin{array}{l}\text { Tidak } \\
\text { Patuh } \\
\text { (orang) } \\
\end{array}$ & $\%$ & $\begin{array}{l}\text { Total } \\
\text { (orang) }\end{array}$ & $\%$ \\
\hline \multicolumn{7}{|l|}{ Jenis kelamin } \\
\hline Laki-laki & 48 & 48,00 & 60 & 42,25 & 108 & 44,63 \\
\hline Perempuan & 52 & 52,00 & 82 & 57,75 & 134 & 55,37 \\
\hline \multicolumn{7}{|l|}{ Usia } \\
\hline$\geq 60$ tahun & 54 & 54,00 & 74 & 52,11 & 128 & 52,89 \\
\hline 50 - 59 tahun & 22 & 22,00 & 33 & 23,24 & 55 & 22,73 \\
\hline 40 - 49 tahun & 19 & 19,00 & 27 & 19,01 & 46 & 19,01 \\
\hline$<40$ tahun & 5 & 5,00 & 8 & 5,63 & 13 & 5,37 \\
\hline \multicolumn{7}{|l|}{ Pendidikan } \\
\hline Tinggi & 33 & 33,00 & 39 & 27,46 & 72 & 29,75 \\
\hline Rendah & 67 & 67,00 & 103 & 72,54 & 170 & 70,25 \\
\hline \multicolumn{7}{|l|}{ Pekerjaan } \\
\hline Formal & 20 & 20,00 & 17 & 11,97 & 37 & 15,29 \\
\hline Non-formal & 80 & 80,00 & 125 & 88,03 & 205 & 84,71 \\
\hline \multicolumn{7}{|c|}{ Pendapatan keluarga perbulan } \\
\hline$>\operatorname{Rp} 1.700 .000$ & 62 & 62,00 & 75 & 52,82 & 137 & 56,61 \\
\hline$\leq \operatorname{Rp} 1.700 .000$ & 38 & 38,00 & 67 & 47,18 & 105 & 43,39 \\
\hline \multicolumn{7}{|c|}{ Lama terdiagnosa hipertensi } \\
\hline$\leq 1$ tahun & 13 & 13,00 & 24 & 16,90 & 37 & 15,29 \\
\hline
\end{tabular}

Tingkat kepatuhan pasien hipertensi terhadap pengobatan masih di bawah batas perkiraan WHO (2013) tentang kepatuhan penggunaan obat jangka panjang pada pasienpasien di Negara berkembang yaitu 50\%. Oleh karena itu sebagai dasar intervensi dalam kepatuhan pengobatan, sangat penting untuk menganalisis faktor-faktor yang kemungkinan memiliki hubungan dengan kepatuhan berobat.

Beberapa faktor yang dimaksud, disajikan pada Tabel 2. Dalam penelitian ini juga dilakukan analisis multivariat dengan regresi logistik model dan variabel bebas yang telah memenuhi nilai $\mathrm{p}<0,25$ pada analisis bivariat akandiikutsertakan dalam seleksi multivariat untuk dianalisis secara bersama-sama dengan tujuan mengetahui variable yang paling dominan berhubungan dengan kepatuhan berobat.

Hasil analisis multivariat menunjukan komorbiditas merupakan variabel yang paling dominan berhubungan dengan kepatuhan berobat penderita hipertensi $(\mathrm{OR}=3,943$, CI $95 \%=1,470$ $10,575, p$-value $=0,006)$.

Tabel 2. Hasil analisis bivariat (Chi-square) hubungan variabel bebas dengan Kepatuhan berobat penderita hipertensi

\begin{tabular}{|c|c|c|c|c|}
\hline \multirow[b]{2}{*}{ Variabel } & \multicolumn{2}{|c|}{ Kepatuhan Berobat } & \multirow[b]{2}{*}{$\begin{array}{l}\text { OR } \\
\text { (CI95\%) }\end{array}$} & \multirow[b]{2}{*}{$p$ value } \\
\hline & $\begin{array}{l}\text { Patuh } \\
(\%)\end{array}$ & $\begin{array}{l}\text { Tidak patuh } \\
(\%)\end{array}$ & & \\
\hline \multicolumn{5}{|l|}{ Pengetahuan } \\
\hline Baik & $72(72,00 \%)$ & $100(70,42 \%)$ & 1,080 & 0,789 \\
\hline Kurang baik & $28(28,00 \%)$ & $42(29,58 \%)$ & $(0,591-1,986)$ & \\
\hline \multicolumn{5}{|c|}{ Riwayat keluarga hipertensi } \\
\hline Ada & $51(51,00 \%)$ & $76(53,52 \%)$ & 0,903 & 0,699 \\
\hline Tidak ada & $49(49,00 \%)$ & $66(46,48 \%)$ & $(0,524-1,558)$ & \\
\hline \multicolumn{5}{|c|}{ Komorbiditas } \\
\hline Ada & $16(16,00 \%)$ & $8(5,63 \%)$ & 3,190 & $0,007 *$ \\
\hline Tidak ada & $84(84,00 \%)$ & $134(94,37 \%)$ & $(1,218-8,964)$ & \\
\hline
\end{tabular}




\begin{tabular}{|c|c|c|c|c|}
\hline \multirow[b]{2}{*}{ Variabel } & \multicolumn{2}{|c|}{ Kepatuhan Berobat } & \multirow[b]{2}{*}{$\begin{array}{l}\text { OR } \\
(\text { C.I95\%) }\end{array}$} & \multirow[b]{2}{*}{$p$ value } \\
\hline & $\begin{array}{l}\text { Patuh } \\
(\%)\end{array}$ & $\begin{array}{l}\text { Tidak patuh } \\
(\%)\end{array}$ & & \\
\hline \multicolumn{5}{|c|}{ Sikap untuk pengobatan } \\
\hline Positif & $71(71,00 \%)$ & $109(76,76 \%)$ & 0,741 & 0,312 \\
\hline Negatif & $29(29,00 \%)$ & $33(23,24 \%)$ & $(0,398-1,385)$ & \\
\hline \multicolumn{5}{|l|}{$\begin{array}{l}\text { Ketersediaan } \\
\text { obat }\end{array}$} \\
\hline Tersedia & $95(95,00 \%)$ & $141(99,30 \%)$ & 0,134 & $0,045^{*}$ \\
\hline Tidak tersedia & $5(5,00 \%)$ & $1(0,70 \%)$ & $(0,002-1,240)$ & \\
\hline \multicolumn{5}{|c|}{ Aksesibilitas obat } \\
\hline Mudah & $90(90,00 \%)$ & $124(87,32 \%)$ & 1,306 & 0,521 \\
\hline Tidak mudah & $10(10,00 \%)$ & $18(12,68 \%)$ & $(0,540-3,323)$ & \\
\hline \multicolumn{5}{|l|}{ Persepsi jarak } \\
\hline Dekat & $57(57,00 \%)$ & $70(49,30 \%)$ & 1,363 & 0,237 \\
\hline Jauh & $43(43,00 \%)$ & $72(50,70 \%)$ & $(0,789-2,358)$ & \\
\hline \multicolumn{5}{|c|}{ Ketersediaan transportasi } \\
\hline Tersedia & $97(97,00 \%)$ & $137(96,48 \%)$ & 1,180 & 0,563 \\
\hline Tidak tersedia & $3(3,00 \%)$ & $5(3,52 \%)$ & $(0,223-7,771)$ & \\
\hline \multicolumn{5}{|c|}{ Kemudahan konsumsi obat } \\
\hline Mudah & $96(96,00 \%)$ & $128(90,14 \%)$ & 2,62 & 0,068 \\
\hline Tidak mudah & $4(4,00 \%)$ & $14(9,86 \%)$ & $(0,788-11,258)$ & \\
\hline \multicolumn{5}{|c|}{ Dukungan keluarga } \\
\hline Mendukung & $86(86,00 \%)$ & $113(79,58 \%)$ & 1,576 & 0,198 \\
\hline $\begin{array}{l}\text { Tidak } \\
\text { mendukung }\end{array}$ & $14(14,00 \%)$ & $29(20,42 \%)$ & $(0,750-3,429)$ & \\
\hline \multicolumn{5}{|c|}{ Dukungan petugas kesehatan } \\
\hline Mendukung & $89(89,00 \%)$ & $119(83,8 \%)$ & 1,563 & 0,251 \\
\hline $\begin{array}{l}\text { Tidak } \\
\text { mendukung }\end{array}$ & $11(11,00 \%)$ & $23(16,20 \%)$ & $(0,688-3,742)$ & \\
\hline \multicolumn{5}{|c|}{ Asuransi kesehatan } \\
\hline Memiliki & $81(81,00 \%)$ & $125(88,03 \%)$ & 0,579 & 0,130 \\
\hline Tidak memiliki & $19(19,00 \%)$ & $17(11,97 \%)$ & $(0,266-1,258)$ & \\
\hline \multicolumn{5}{|c|}{ Keterpaparan informasi } \\
\hline Pernah & $90(90,00 \%)$ & $135(95,07 \%)$ & 0,466 & 0,128 \\
\hline Tidak pernah & $10(10,00 \%)$ & $7(4,93 \%)$ & $(0,145-1,420)$ & \\
\hline
\end{tabular}

\begin{tabular}{|c|c|c|c|c|}
\hline \multirow[b]{2}{*}{ Variabel } & \multicolumn{2}{|c|}{ Kepatuhan Berobat } & \multirow[b]{2}{*}{$\begin{array}{l}\text { OR } \\
(\mathrm{CI} 95 \%)\end{array}$} & \multirow[b]{2}{*}{$p$ value } \\
\hline & $\begin{array}{l}\text { Patuh } \\
(\%)\end{array}$ & $\begin{array}{l}\text { Tidak patuh } \\
(\%)\end{array}$ & & \\
\hline Jenis kelamin & & & & \\
\hline Laki-laki & $48(48,00)$ & $60(42,25 \%)$ & 1,261 & 0,375 \\
\hline $\begin{array}{l}\text { Perempuan } \\
\text { Usia }\end{array}$ & $52(53,00 \%)$ & $82(57,75 \%)$ & $(0,729-2,179)$ & \\
\hline $\begin{array}{l}\text { Dewasa tua } \\
(50-59 ; \geq 60 \text { tahun })\end{array}$ & $76(76,00 \%)$ & $107(75,35 \%)$ & 1,035 & 0,908 \\
\hline $\begin{array}{l}\text { Dewasa muda } \\
(<\quad 40 ; 40 \quad-49 \\
\text { tahun) }\end{array}$ & $24(24,00 \%)$ & $35(24,65 \%)$ & $(0,548-1,978)$ & \\
\hline
\end{tabular}




\begin{tabular}{|c|c|c|c|c|}
\hline \multirow[b]{2}{*}{ Variabel } & \multicolumn{2}{|c|}{ Kepatuhan Berobat } & \multirow[b]{2}{*}{$\begin{array}{l}\text { OR } \\
(\mathrm{CI} 95 \%)\end{array}$} & \multirow[b]{2}{*}{ p value } \\
\hline & $\begin{array}{l}\text { Patuh } \\
(\%)\end{array}$ & $\begin{array}{l}\text { Tidak patuh } \\
(\%)\end{array}$ & & \\
\hline \multicolumn{5}{|l|}{ Pendidikan } \\
\hline Tinggi & $33(33,00 \%)$ & $39(27,46 \%)$ & 1,300 & 0,353 \\
\hline Rendah & $67(67,00 \%)$ & $103(72,54 \%)$ & $(0,716-2,353)$ & \\
\hline \multicolumn{5}{|l|}{ Pekerjaan } \\
\hline Formal & $20(20,00 \%)$ & $17(11,97 \%)$ & 1,838 & 0,087 \\
\hline Non-formal & $80(80,00 \%)$ & $125(88,03 \%)$ & $(0,854-3,974)$ & \\
\hline \multicolumn{5}{|c|}{ Pendapatan keluarga per-bulan } \\
\hline$>$ Rp 1.700.000 & $62(62,00 \%)$ & $75(52,82 \%)$ & $\begin{array}{l}1,45 \\
7\end{array}$ & 0,155 \\
\hline$\leq \operatorname{Rp} 1.700 .000$ & $38(38,00 \%)$ & $67(47,18 \%)$ & $(0,838-2,542)$ & \\
\hline \multicolumn{5}{|c|}{ Lama terdiagnosa hipertensi } \\
\hline$\leq 1$ tahun & $13(13,00 \%)$ & $24(16,90 \%)$ & $\begin{array}{l}0,73 \\
4\end{array}$ & 0,406 \\
\hline$>1$ tahun & $87(87,00 \%)$ & $118(83,10 \%)$ & $(0,324-1,603)$ & \\
\hline
\end{tabular}

Ket: *: Signifikan $(\mathbf{p}<0.05)$

Pasien hipertensi yang memiliki penyakit penyerta berisiko 3,94 kali untuk patuh melakukan pengobatan dibandingkan dengan pasien hipertensi tanpa penyakit penyerta. Keberadaan variabel perancu tidak diperhitungkan dalam penelitian ini. Tahapan selanjutnya dalam analisis multivariat adalah melakukan uji kolinearitas dengan tujuan mengetahui hubungan antara variabel bebas pada model. Hasil uji menunjukan bahwa tidak ditemukan adanya kolinearitas antar variabel bebas. Adapun hasil analisis multivariat disajikan pada Tabel 3 .

Tabel 3. Hasil analisis multivariat (logistic regression) hubungan beberapa variabel bebas secara bersama-sama dengan kepatuhan berobat penderita hipertensi

\begin{tabular}{|c|c|c|c|}
\hline \multirow[t]{2}{*}{ Variabel } & Model 1 & Model 2** & Model 3 \\
\hline & $\begin{array}{c}\text { OR } \\
\text { CI 95\% } \\
\text { p-value }\end{array}$ & $\begin{array}{c}\text { OR } \\
\text { CI 95\% } \\
p \text {-value }\end{array}$ & $\begin{array}{c}\text { OR } \\
\text { CI 95\% } \\
p \text {-value }\end{array}$ \\
\hline \multirow[t]{2}{*}{ Komorbiditas } & $\begin{array}{r}3,745 \\
(1,397-10,034)\end{array}$ & $\begin{array}{r}3,943 \\
(1,470-10,57)\end{array}$ & $\begin{array}{r}3,848 \\
(1,441-10,27)\end{array}$ \\
\hline & $0,009^{*}$ & $0,006^{*}$ & $0,007 *$ \\
\hline \multirow[t]{3}{*}{ Ketersediaan obat } & 0,153 & 0,133 & \\
\hline & $(0,017-1,377)$ & $(0,014-1,196)$ & \\
\hline & 0,094 & 0,072 & \\
\hline \multirow[t]{2}{*}{ Persepsi jarak } & $\begin{array}{r}1,620 \\
(0,898-2,922)\end{array}$ & & $\begin{array}{r}1,707 \\
(0,951-3,063)\end{array}$ \\
\hline & 0,109 & & 0,073 \\
\hline \multirow[t]{2}{*}{ Kemudahan konsumsi obat } & $\begin{array}{r}5,672 \\
(1425-22574\end{array}$ & $\begin{array}{r}5,748 \\
(1462-2559)\end{array}$ & $\begin{array}{r}5,784 \\
(1460-2204)\end{array}$ \\
\hline & $0,014^{*}$ & $0,012 *$ & $0,012 *$ \\
\hline \multirow[t]{3}{*}{ Dukungan keluarga } & 2,392 & 1,992 & 2,478 \\
\hline & $(1,062-5,388)$ & $(0,918-4,319)$ & $(1,109-5,538)$ \\
\hline & $0,035^{*}$ & 0,081 & $0,027 *$ \\
\hline
\end{tabular}




\begin{tabular}{lrrr}
\hline Asuransi kesehatan & 0,398 & 0,442 & 0,412 \\
& $(0,174-0,907)$ & $(0,197-0,993)$ & $(0,181-0,939)$ \\
Keterpaparan informasi & $0,028^{*}$ & $0,048^{*}$ & $0,035^{*}$ \\
& 0,326 & 0,321 & 0,412 \\
Pendapatan per-bulan & $(0,106-0,996)$ & $(0,106-0,974)$ & $(0,111-1,037)$ \\
& 1,808 & 1,709 & 1,824 \\
& $(1,014-3,224)$ & $(0,969-3,012)$ & $(1,028-3,238)$ \\
\hline BIC & $0,044^{*}$ & 0,064 & $0,040^{*}$ \\
\hline
\end{tabular}

Ket: $\quad * \quad$ : Signifikan $(\mathrm{p}<0,05)$

** : Model final

BIC : Bayesian Information Criterion

\section{PEMBAHASAN}

Hasil analisis univariat menyatakan bahwa responden penelitian terdiri dari 108 (44,63\%) laki-laki dan 134 (55,37\%) perempuan. Hasil dari beberapa penelitian global juga menunjukan bahwa hampir disemua Negara kejadian hipertensi lebih tinggi pada perempuan dibandingkan laki-laki. Usia responden paling banyak yaitu usia dewasa tua ( $\geq 60$ tahun) sebanyak $128 \quad(52,89 \%)$ pasien dan paling sedikit usia dewasa muda ( $<40$ tahun) yaitu sebanyak 13 $(5,37 \%)$ pasien. Sebagai bagian dari penyakit kronis, kejadian hipertensi akan mengalami peningkatan seiring dengan peningkatan usia.Dari 242 pasien menunjukan bahwa sebagian besar pasien masih berpendidikan rendah $170(70,25 \%)$ dan sebanyak $72(29,75 \%)$ pasien yang berpendidikan tinggi. Dalam penelitian ini responden dikategorikan berpendidikan rendah apabila telah menempuh pendidikan terakhir sampai jenjang SMP ke bawah sedangkan responden dikategorikan berpendidikan tinggi apabila telah menempuh pendidikan terakhir sampai jenjang SMA ke atas.

Dari sisi pekerjaan pasien menunjukan bahwa $84,71 \%$ pasien bekerja pada sektor nonformal dan $15,29 \%$ pasien yang sudah bekerja di sektor formal. Responden yang dikategorikan memiliki pekerjaan non-formal, jika tidak memiliki pekerjaan terikat dengan instansi tertentu dan jam kerja yang tertentu. Apabila dilihat dari karakteristik pendapatan keluarga perbulan, bila dibandingkan dengan UMK Kabupaten Gianyar tahun 2015 sudah tergolong baik. Sebanyak $137(56,61 \%)$ pasien memiliki pendapatan melebihi UMK dan sebanyak 105 $(43,39 \%)$ pasien yang masih memiliki pendapatan dibawah UMK. UMK Gianyar pada tahun 2015 yaitu $\mathrm{Rp}$ 1.700.000. Sedangkan apabila dilihat dari lamanya terdiagnosa hipertensi, sebagian besar $(84,71 \%)$ pasien telah didiagnosa menderita hipertensi $>1$ tahun. Untuk memaksimalkan tingkat kepatuhan pasien hipertensi dalam pengobatan, sangat penting untuk menganalisis faktor-faktor yang kemungkinan memiliki hubungan dengan kepatuhan berobat. Hasil analisis bivariat variabel komorbiditas dengan kepatuhan berobat diperoleh nilai $\mathrm{p}=0,007$ yang secara statistik menunjukan adanya hubungan yang signifikan antara variabel komorbiditas dengan kepatuhan berobat pasien hipertensi. Nilai $\mathrm{OR}=3,190, \mathrm{CI}$ 95\%=1,218-8,964 yang menunjukan bahwa pasien hipertensi yang memiliki penyakit penyerta berisiko 3,190 kali lebih besar untuk patuh melakukan pengobatan dibandingkan dengan penderita hipertensi yang tidak memiliki penyakit penyerta. Keberadaan penyakit penyerta memiliki hubungan dengan kepatuhan berobat, namun pasien dengan komorbiditas perlu mendapatkan perhatian terkait dengan obat-obatan yang digunakan pasien, yang kemungkinan memiliki potensi menyebabkan terjadinya interaksi obat sehingga dapat menghambat keberhasilan terapi. Penyakit-penyakit penyerta potensial yang dapat memperburuk hipertensi harus mendapatkan pengobatan yang optimal untuk mendukung tercapainya pengontrolan tekanan darah pada pasien hipertensi (Saepudin. Dkk, 2013).

Pada hasil analisis bivariat lainnya, secara statistik menunjukan bahwa terdapat hubungan yang signifikan antara variabel ketersediaan obat dengan kepatuhan berobat $(\mathrm{p}=0,045)$. Namun nilai OR sebesar 0,134 menandakan bahwa variabel ketersediaan obat merupakan faktor protektif terhadap kepatuhan berobat. Hal ini kemungkinan dipengaruhi oleh kecondongan yang sangat besar antara persentase responden yang menyatakan obat tersedia setiap kali melakukan pengobatan ke Puskesmas dibandingkan dengan persentase responden yang menyatakan obat tidak tersedia. Dari hasil observasi terhadap pasien hipertensi sebagian besar pasien menyatakan bahwa obat selalu tersedia setiap kali pasien datang untuk 
berobat ke Puskesmas Payangan. Namun ketersediaan obat antihipertensi di Puskesmas Payangan perlu ditinjau kembali apakah sudah memenuhi standar manajemen ketersediaan obat secara nasional baik menyangkut pengadaan dan penyimpanan obat (Meinema., et al, 2015).

Hasil model final dari analisis regresi logistik, menunjukan bahwa terdapat empat variabel yang berhubungan dengan kepatuhan berobat. Keempat variabel tersebut adalah komorbiditas $(\mathrm{p}=0,006, \mathrm{OR}=3,943)$, kemudahan konsumsi obat $(\mathrm{p}=0,012, \mathrm{OR}=5,748)$, asuransi kesehatan $(\mathrm{p}=0,048, \mathrm{OR}=0,442)$ dan keterpaparan informasi $(p=0,045, O R=0,321)$. Satu variable yang dominan berhubungan dengan kepatuhan berobat pasien hipertensi di wilayah kerja Puskesmas Payangan adalah komorbiditas $(\mathrm{p}=0,006, \mathrm{OR}=3,943$, CI 95\%=1,470-10,575).

Pasien hipertensi yang memiliki penyakit penyerta berisiko 3,94 kali untuk patuh melakukan pengobatan dibandingkan dengan pasien hipertensi tanpa penyakit penyerta. Selain itu, pasien hipertensi yang merasakan takaran dan dosis obat yang diberikan memudahkan obat tersebut untuk dikonsumsi berisiko 5,74 kali untuk patuh melakukan pengobatan dibandingkan dengan pasien hipertensi yang merasakan takaran dan dosis obat yang diberikan mempersulit obat tersebut untuk dikonsumsi. Kebanyakan pasien yang merasakan bahwa obat antihipertensi mudah dikonsumsi yaitu obat antihipertensi yang dianjurkan untuk diminum 1xsehari yang berarti pasien cenderung lebih patuh apabila mengkonsumsi obat antihipertensi dengan jumlah kecil setiap harinya (Napolitano, dkk, 2015). Dalam hal kepemilikan asuransi kesehatan, secara statistik menunjukan variabel asuransi kesehatan merupakan faktor protektif terhadap kepatuhan berobat $(\mathrm{OR}=0,442)$. Asuransi kesehatan merupakan bagian dari pembiayaan pengobatan pasien hipertensi, menurut penelitian yang dilakukan oleh Haryanti et al., (2012) tentang analisis pengaruh biaya obat terhadap kepatuhan kontrol pasien hipertensi, menunjukan bahwa biaya pengobatan hanya berkontribusi sebesar $0,2 \%$ terhadap kepatuhan berobat pasien hipertensi. Sehingga dengan kepemilikan asuransi kesehatan belum

menjamin pasien untuk lebih patuh melakukan pengobatan Haryanti, dkk, 2012). Model 2 juga menunjukan variabel keterpaparan informasi merupakan faktor protektif terhadap kepatuhan berobat $(\mathrm{OR}=0,321)$. Berbagai informasi yang berhubungan dengan pengobatan seperti cara pengambilan obat, gejala penyakit, diet dan efek samping obat pernah didapatkan oleh pasien hipertensi. Namun keterpaparan informasi erat hubungannya dengan recall bias yaitu kemampuan mengingat kembali informasi yang didapat. Sehingga informasi yang pernah didapat belum menjamin pasien akan lebih patuh melakukan pengobatan (Magnabosc., et al. 2015).

Hasil penelitian ini menyatakan bahwa komorbiditas merupakan salah satu variabel yang paling berkontribusi untuk merubah perilaku pasien hipertensi agar lebih patuh melakukan pengobatan. Untuk pasien dengan komorbiditas, kepatuhan berobat sangat penting dilakukan karena ketidakpatuhan dalam penggunaan obat pada pasien hipertensi sangat potensial mempercepat terjadinya komplikasi penyakit yang dapat meningkatkan morbiditas dan mortalitas. Tingkat kepatuhan yang tinggi terbukti sangat efektif mengurangi risiko komplikasi penyakit pada pasien hipertensi (Mazzaglia, et al., 2009). Beberapa alasan dimana pasien dengan penyakit penyerta lebih patuh untuk melakukan pengobatan yaitu pasien dengan penyakit penyerta akan lebih sering berkunjung ke Puskesmas, pasien dengan penyakit penyerta memiliki perhatian besar untuk kesembuhannya, dan pasien dengan penyakit penyerta lebih sering untuk melakukan pengobatan secara berlanjut.

\section{KESIMPULAN}

Berdasarkan hasil penelitian, dapat disimpulkan bahwa tingkat kepatuhan berobat pasien hipertensi di wilayah kerja Puskesmas Payangan Kabupaten Gianyar Provinsi Bali masih rendah . Variabel komorbiditas dan ketersediaan obat memiliki hubungan bermakna dengan kepatuhan berobat dimana dari analisis regresi logistik model, komorbiditas merupakan variabel yang paling dominan berhubungan dengan kepatuhan berobat. Untuk memaksimalkan kemungkinan kepatuhan, perlu meningkatkan interaksi profesional kesehatan diantara pasien tanpa komorbiditas. Sedangkan pasien dengan komorbiditas perlu mendapatkan perhatian terkait dengan obat-obatan yang dikonsumsi, yang kemungkinan memiliki potensi menyebabkan terjadinya interaksi obat sehingga dapat menghambat keberhasilan terapi. Selain itu, pihak Puskesmas perlu melakukan modifkasi data rekam medis dengan penambahan item yang mendefinisikan bahwa pasien hipertensi yang berobat ke Puskesmas Payangan merupakan pasien komorbiditas atau tanpa komorbiditas. Sehingga membantu dalam program pengobatan penyakit hipertensi yang lebih komprehensif. Penelitian lebih lanjut untuk menentukan bagaimana mengatasi kendala ketersediaan obat antihipertensi juga perlu dilakukan. 


\section{DAFTAR PUSTAKA}

Al-Hajje, A., Awada, S., Rachidi, S., Zein, S., Bawab, W., Elhajj, Z., Zeid, B.M., Yassine, M., Salameh, P. (2015) Evaluation of Medication Adherence in Lebanese Hypertensive Patients, Ann. Med. Health Sci. Res., 5(3): 173-178.

Armelia, H. (2011) Hubungan Dukungan Sosial Terhadap Pencegahan Kekambuhan Penyakit Hipertensi di Badan Layanan Umum Rumah Sakit Dr Pirngadi. Tesis. Universitas Sumatera Utara

Badan Pusat Statistik. (2013), Proyeksi Penduduk Indonesia (Indonesia Population Projection) 2010-2035, Jakarta: Badan Pusat Statistik Nasional.

Barreto, Mda.S., Reiners, A.A., Marcon, S.S. (2014) Knowledge about Hypertension and Factors Associated with the Non-Adherence to Drug Therapy, Rev. Lat Am. Enfermagem, 22(3): 491-498.

Dinas Kesehatan Provinsi Bali. (2013), Laporan Tahunan Penyakit Tidak Menular

Provinsi Bali Tahun 2013.Denpasar: Dinas Kesehatan Provinsi Bali.

Dinas Kesehatan Kabupaten Gianyar. (2013), Laporan Tahunan Kesehatan Kabupaten Gianyar Tahun 2013. Gianyar: Dinas Kesehatan Kabupaten Gianyar

Dusing, G., Rainer, D., Lotternoser, K., Mengden, T. (2001) Compliance to Drug

Therapy-New Answer to an Old Question, Nephrol Dial Transpl., 16(4): 1317- 1321.

Haryanti, Y.D., Subagio, P.B., Fajrin, F.A. (2012) Analisis Pengaruh Biaya Obat terhadap Kepatuhan Kontrol Pasien Hipertensi di Instalasi Rawat Jalan RSD dr.Soebandi Jember Periode Bulan Januari-Juni 2012. Tesis. Universitas Jember.

Hawe, P., Degeling, D., Hall, J. (1991) Evaluating Health Promotion. Australia:

MacLennan \& Petty Pty Limited.

Kementrian Kesehatan Republik Indonesia. (2007), Profil Kesehatan Indonesia 2006. Jakarta: Direktorat Jenderal Pengendalian Penyakit dan Penyehatan Lingkungan.

Khanam, M.A., Lindeboom, W., Koehlmoons, T.L., Alam, D.S., Niessen, L., Molton, A.H. (2014) Hypertension: Adherence to Treatment in Rural Bangladesh - Findings from a Population-Based Study, Glob. Health Action, 10(7): 864-869.

Magnabosco, P., Cavalari, E., de Oliveira, E.M., Felipe, E., Freitas, D. (2015) Comparative Analysis of Non-Adherence to Medication
Treatment for Systemic Arterial Hypertension in Urban and Rural Populations, Rev Lat Am Enfermagem, 23(1): 20-7.

Mazzaglia, G., Ambrosioni, E., Alacqua, M., Filippi, A., Sessa, E., Immordino, V., Borghi, O., Caputi, A.P., Cricelli, C., Mantovani, L.G. (2009) Adherence to Antihypertensive Medications and Cardiovascular Morbidity among Newly Diagnosis Hypertensive Patients, Circulation, 120(16):1598-1605.

Meinema, J.G., van Dijk, N., Beune, E.J., Jaarsma, D.A., van Weert,H.C.,Haafkens, J.A. (2015) Determinants of Adherence to Treatment in Hypertensive Patients of African Descent and the Role of Culturally Appropriate Education, PLoS ONE, 10(8): e0133560.

Morisky, D.E., Ang, A., Krousel-Wood, M., Ward, HJ. (2008) Predictive Validity of a Medication Adherence Measure in an Outpatient Setting, The Journal of Clinical Hypertension, 10(5): 348-354.

Napolitano, F., Napolitano, P., Angelillo, I.F. (2015) Medication Adherence Among Patients with Chronic Conditions in Italy. Dissertation: Oxford University.

Riyanto, A. (2010) Pengolahan dan Analisis Data Kesehatan. Yogyakarta: Mulia Medika.

Saeed, K.M., Rasooly, M.H., Brown, N.J. (2012) Prevalence and Predictors of Adult Hypertension in Kabul Afghanistan, BMC Public Health, 10(14): 1471- 1479.

Saepudin, Padmasari, S., Hidayanti, P., Endang, S., Ningsih. (2013) Kepatuhan Penggunaan Obat Pada Pasien Hipertensi di Puskesmas. Jurnal Farmasi Indonesia, 6(4): 246-253.

Unit Pelayanan Teknis Kesehatan Masyarakat Payangan. (2014) Laporan Kasus Baru dan Kasus Lama Penyakit Tidak Menular Tahun 2014. Gianyar: UPT Kesmas Payangan.

World Health Organization. (2012) Expert Consultation on Diet, Nutrition and The Prevention Of Chronic Diseases, Geneva: World Health Organization.

World Health Organization. (2013) A Global Brief on Hypertension, Available at: <www.who.int/cardiovascular_diseases /publications/ global_brief_hypertensi on/en/> [Accessed: 2014, October 9]

Yashar, M., Saadat, H., Babak, N.S., Rai, A., Saadat, Z., Aerab-Sheibani, H., Naghizadeh, M.M., Morisky, D.E. (2014) Validation of the Persian Version of the 8-item Morisky Medication Adherence Scale (MMAS-8) in 
Iranian Hypertensive Patients, Global Journal of Health Science, 7(4): 173-183

Yue, Z., Bin, W., Weilin, Q., Aifang, Y. (2014) Effect of Medication Adherence on
Blood Pressure and Risk Factors for Antihypertensive Medication Adherence, $J$. Eval Clin Pract, 21(1): 166-17 
Purnawan, I.N / Kesehatan Terpadu 3(1) (2019) 